\title{
Cutaneous Metastasis of Esophageal Squamous Cell Carcinoma (ESCC)
}

\author{
Sridhar $\mathbf{P}^{1}$, Nihanthy D S ${ }^{2}$, Pallad S.R ${ }^{3}$, Naveen $T^{4}$, Khaleel I ${ }^{5}$, Govardhan ${ }^{6}$ \\ ${ }^{1}$ Dr Sridhar P, Assistant Professor, ${ }^{2}$ Dr Nihanthy D S, Resident, ${ }^{3}$ Dr Siddanna R Pallad, Associate Professor, ${ }^{4}$ Dr Naveen \\ T, Associate Professor, ${ }^{5}$ Dr Ibrahim Khaleel, Assistant Professor, ${ }^{6}$ Dr Govardhan, Assistant Professor; all authors are \\ affiliated with Department of Radiation Oncology, Kidwai Memorial Institute of Oncology, Bangalore, India.
}

Address for Correspondence: Dr Nihanthy D S, Resident in Radiation Oncology, Kidwai Memorial Institute of Oncology, Bangalore, India, email id: nihanthyds@gmail.com

\begin{abstract}
Introduction: Esophageal cancer is an aggressive disease with a poor prognosis. Patients generally present at an advanced stage. The most predominant histologically subtype is squamous cell carcinoma comprising about $70 \%$ of cases. The skin is an uncommon site of metastasis, skin metastasis from esophageal cancer affects less than $1 \%$ of the cases. Metastatic spread to the skin occurs either hematogenously or via the lymphatic system and a myriad of presentations may be seen. Materials and Methods: A 30-year-old male, a known case of carcinoma esophagus post concurrent CT-RT, three months ago, presented to the OPD with complaints of burning sensation and multiple solid skin nodules, measuring about $1-3 \mathrm{~cm}$ in diameter over the left chest, after thorough evaluation and biopsy of the skin lesion the final diagnosis of cutaneous metastasis of metastasic esophageal squamous cell carcinoma was established. Planned on palliative RT, pt received an External beam RT of 30Gy in 10 fractions on $6 \mathrm{MeV}$ electrons at a depth of $3 \mathrm{~cm}$. Result: Patient is symptom free with complete response of the skin nodules. Conclusion: Cutaneous metastasis from internal malignancy is uncommon but not rare and is reported most commonly after the fourth decade of life. Skin metastasis from upper GI tract is relatively infrequent and esophageal cancer rarely metastasize cutaneousely, ESCC with diffuse and skin involvement is an indicator of highly aggressive nature of the disease. There are very few reported cases and hereby reporting a rare case treated at our Institution.
\end{abstract}

Keywords: ESCC-Esophageal Squamous Cell Carcinoma, RT- Radiotherapy, CT- Chemotherapy, GTV- Gross tumor volume, 3DCRT- Three dimensional conformal radiotherapy.

\section{Introduction}

Esophageal cancer is a highly aggressive disease with poor prognosis. Patients generally present with locally advanced disease, which has already metastasized at the time of initial diagnosis. The most predominant histologically subtype is squamous cell carcinoma comprising about $70 \%$ of cases [1].
The skin is an uncommon site of metastasis, skin metastasis from esophageal cancer affect less than $1 \%$ of cases [2, 3]. Metastatic spread to the skin occurs either hematogenously or via the lymphatic system with a myriad of presentations, in the form of rapidly growing papules or nodules $[4,5]$. However nodules are the most common form $[6,7,8]$.

\section{Case report}

A 30-year-old male presented with history of dysphagia for solids since 3 months and history of significant weight loss since 2 months. Oesophageogastroduodenoscopy and computerized tomography showed lower-thoracic esophageal growth with extension into Gastroesophageal junction with regional lymph node enlargement rendering the tumor

Manuscript received $10^{\text {th }}$ August 2016

Reviewed: 20 $0^{\text {th }}$ August 2016

Author Corrected: $4^{\text {th }}$ September 2016

Accepted for Publication $14^{\text {th }}$ September 2016 
inoperable. Histology showed features suggestive of squamous cell carcinoma. No extra-nodal or pulmonary metastases were noticed. Patient was treated with concurrent CT-RT, received a biological equivalent dose of 54Gy to the GTV on linac by 3DCRT technique along with six cycles of concurrent weekly cisplatin $(40 \mathrm{mg} / \mathrm{m} 2)$.

Patient was asymptomatic for 3 months, presented to the OPD, with complaints of burning sensation and multiple skin nodules over the left anterior chest wall since past two weeks, acute in onset and rapidly progressing to attain the present size. On examination, multiple nodules were present on the left anterior chest wall, hard in consistency, coalesced, largest measuring around $3 \mathrm{~cm}$ in diameter. Excisional Biopsy of the skin lesion showed metastatic squamous cell carcinoma. CT thorax showed partial response of the primary tumor and hence we arrived at the final diagnosis of cutaneous metastasis of metastasic esophageal squamous cell carcinoma.
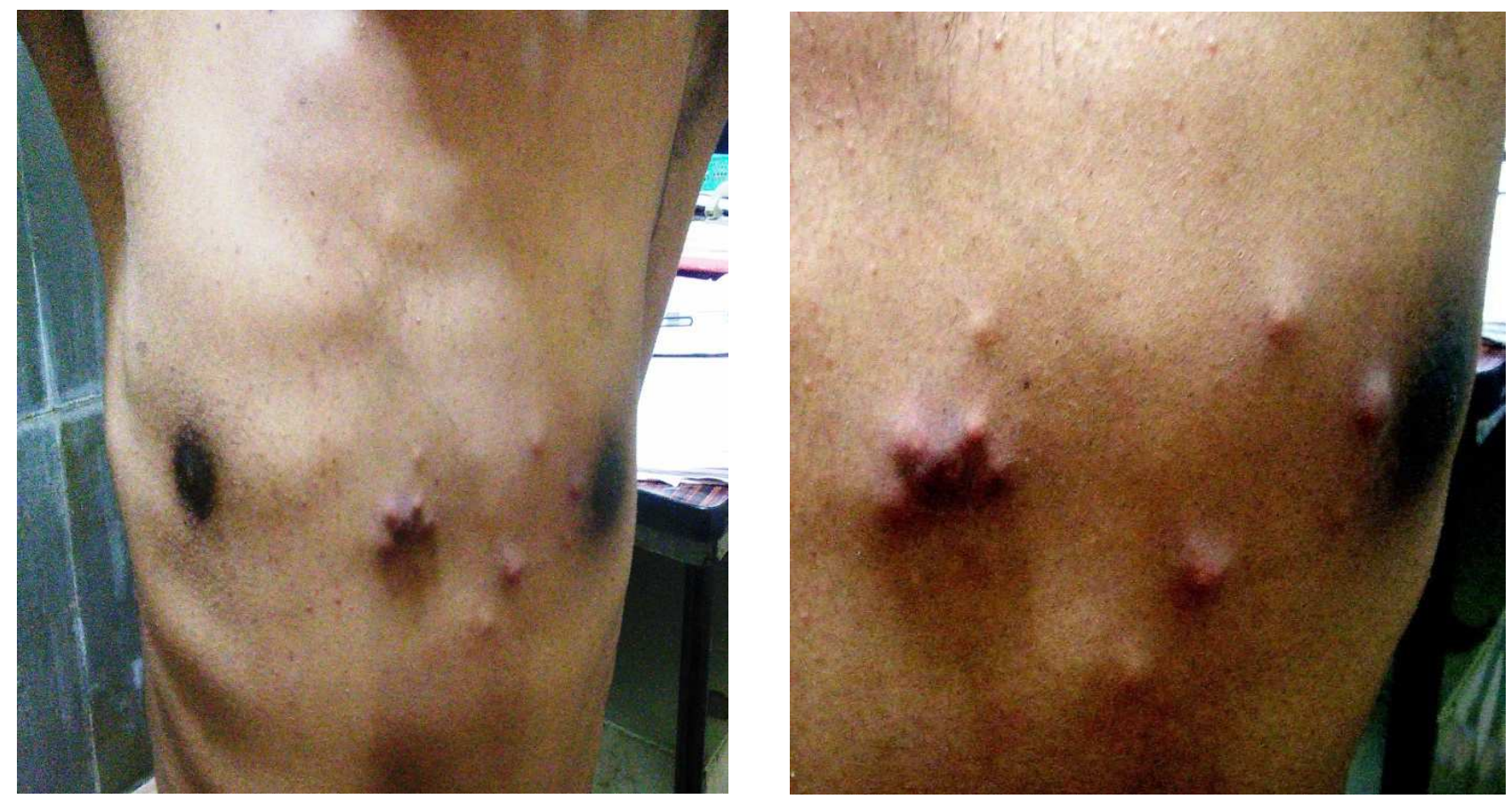

Fig 1: nodular metastasis before therapy
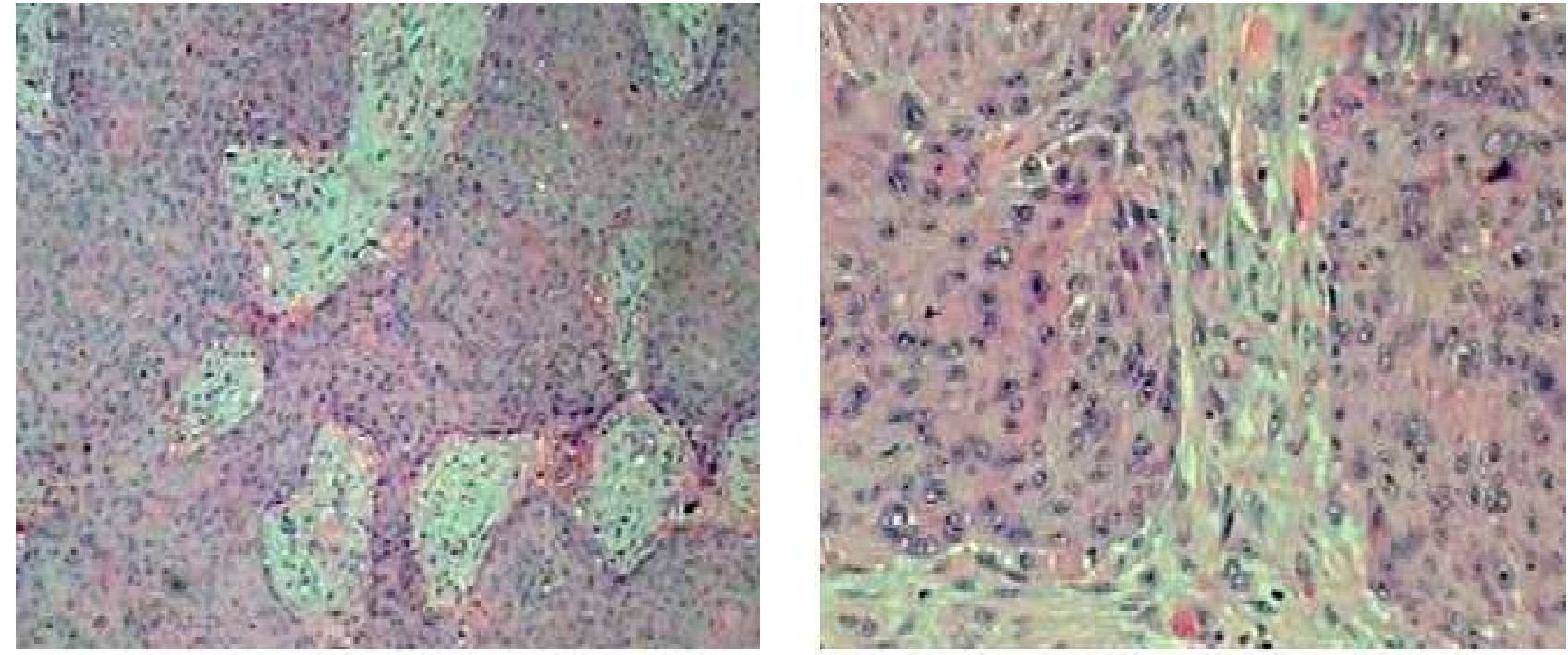

Disorganised sheets of malignant cells with hyperchromatic pleomorphic nuclei, increased nucleus/cytoplam ratio, increased mitoses and bizarre malignant cells consistent with matastatic squamous cell carcinoma. 

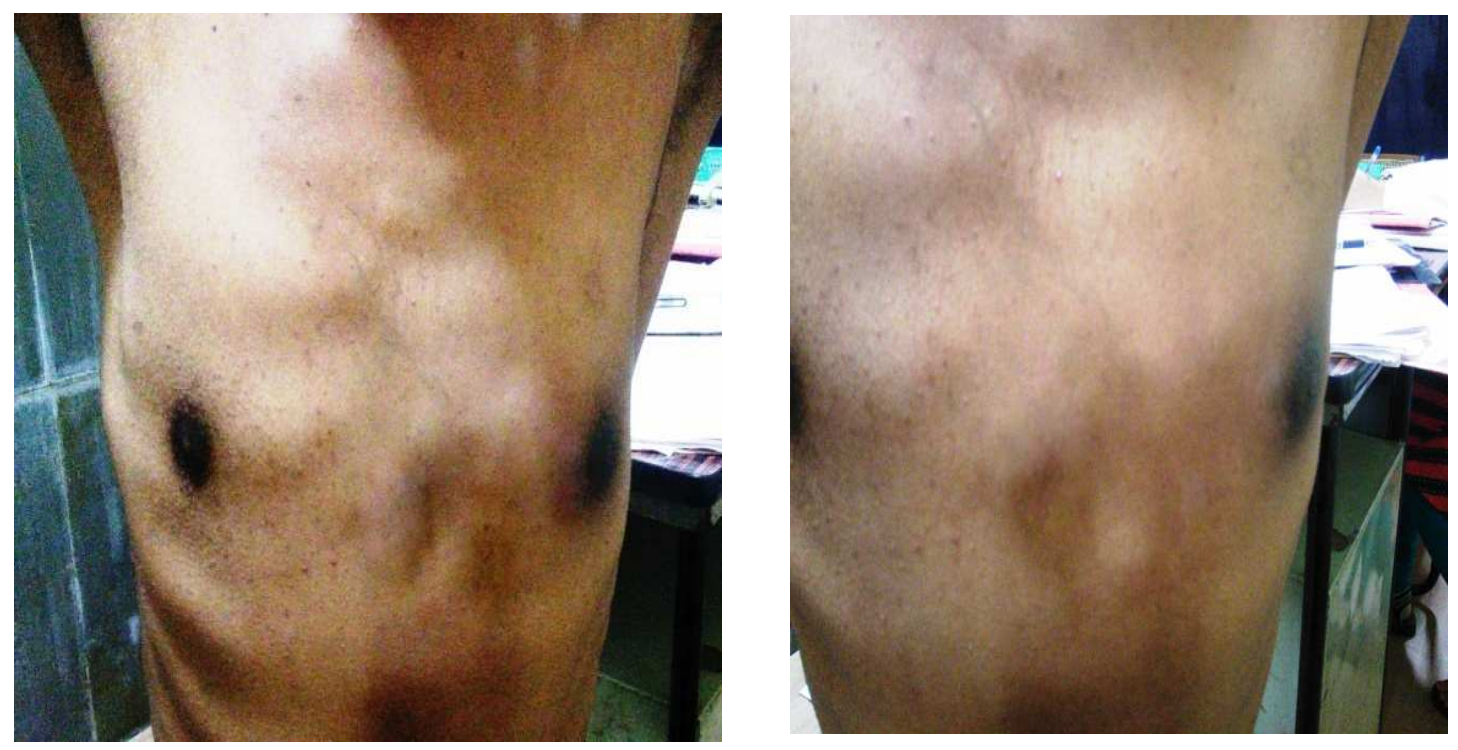

Fig 2: Post Palliative Radiotherapy

Patient was planned on palliative radiation of $30 \mathrm{~Gy}$ in 10 fractions on $6 \mathrm{MeV}$ electrons at a depth of $3 \mathrm{~cm}$. Patient is symptom free with complete response to local palliative therapy.

\section{Discussion}

Cutaneous metastasis from internal malignancy is uncommon but not rare. Their frequency ranges between $0.7 \%$ and $10.4 \%$ of all patients with cancer. [9-14].

Cutaneous metastasis can occur anytime in the course of malignancy. Especially in an extensively metastatic disease, they may also represent failure of ongoing therapy or recurrence of neoplasm. Every cancer can cause skin metastases, but some do so more frequently than others. The most frequent primary nondermatological tumors associated with skin.

Metastases include breast, lung and colorectal cancers. Skin metastasis from upper GI tract is relatively infrequent [11-16], esophageal cancer rarely metastasize cutaneousely.

Most reported esophageal cancers were squamous cell carcinoma but there were some case reports of skin metastases from esophageal adenocarcinoma $[17,18]$.

Due to the extreme rarity of cutaneous metastasis from esophageal squamous cell carcinoma, there are only limited data in the literature regarding their incidence that is less than $1 \%$, prognosis at this stage is quite poor and average survival with the life expectancy for all stage IV esophageal carcinoma ranges from 4 to 20 months after diagnosis [19].

\section{Conclusion}

Skin manifestations of Esophageal squamous cell carcinoma (ESCC) are extremely rare and only a small number of cases with solid skin metastasis have been reported. A case of ESCC with such diffuse and massive skin metastases, most likely indicating highly aggressive disease, although metastatic skin cancers often require no more than symptomatic therapy and tend to respond to systemic chemotherapy, local treatment like radiotherapy to be considered at this stage mainly focuses on palliation.

Funding: Nil, Conflict of interest: None initiated, Permission from IRB: Yes

\section{References}

1. Parkin DM, Bray F, Ferlay J, Pisani P. Estimating the world cancer burden: Globocan 2000. Int J Cancer. 2001 Oct 15;94(2):153-6.

2. Hu SC, Chen GS, Wu CS, Chai CY, Chen WT, Lan CC. Rates of cutaneous metastases from different internal malignancies: experience from a Taiwanese medical center. J Am Acad Dermatol 2009;60:379-87.

3. Quint LE, Hepburn LM, Francis IR, Whyte RI, Orringer MB. Incidence and distribution of distant metastases from newly diagnosed esophageal carcinoma. Cancer. 1995 Oct 1;76(7):1120-5. 
4. Lookingbill DP, Spangler N, Helm KF. Cutaneous metastases in patients with metastatic carcinoma: a retrospective study of 4020 patients. J Am Acad Dermatol. 1993 Aug;29(2 Pt 1):228-36.

5. Schwartz RA. Cutaneous metastatic disease. J Am Acad Dermatol. 1995 Aug;33(2 Pt 1):161-82; quiz 183-6.

6. Stein RH, Spencer JM. Painful cutaneous metastases from esophageal carcinoma. Cutis. 2002 Oct;70(4): 230-2.

7. Fereidooni F, Kovacs K, Azizi MR, Nikoo M. Skin metastasis from an occult esophageal adenocarcinoma. Can J Gastroenterol. 2005 Nov;19(11):673-6.

8. Park JM, Kim DS, Oh SH, Kwon YS, Lee KH. A case of esophageal adenocarcinoma metastasized to the scalp. Ann Dermatol. 2009 May;21(2):164-7. doi: 10. 5021/ad.2009.21.2.164. Epub 2009 May 31.

9. Spencer PS, Helm TN. Skin metastases in cancer patients. Cutis. 1987 Feb;39(2):119-21.

10. Lookingbill DP, Spangler N, Sexton FM. Skin involvement as the presenting sign of internal carcinoma. A retrospective study of 7316 cancer patients. J Am Acad Dermatol 1990; 22(1): 19-26.

11. Lookingbill DP, Spangler N, Helm KF. Cutaneous metastases in patients with metastatic carcinoma: a retrospective study of 4020 patients. J Am Acad Dermatol. 1993 Aug;29(2 Pt 1):228-36.
12. McWhorter JE, Cloud AW. MALIGNANT TUMORS AND THEIR METASTASES: A SUMMARY OF THE NECROPSIES ON EIGHT HUNDRED SIXTY-FIVE CASES PERFORMED AT THE BELLEVUE HOSPITAL OF NEW YORK. Ann Surg. 1930 Sep;92(3):434-43.

13. ENTICKNAP JB. An analysis of 1,000 cases of cancer with special reference to metastasis. Guys Hosp Rep. 1952;101(4):273-9.

14. Schwartz RA. Cutaneous metastatic disease. J Am Acad Dermatol. 1995 Aug;33(2Pt 1):161-82; quiz183-6.

15. Sarid D, Wigler N, Gutkin Z, Merimsky O, LeiderTrejo L, Ron IG. Cutaneous and subcutaneous metastases of rectal cancer. Int J Clin Oncol. 2004 Jun; 9(3):202-5.

16. Brownstein MH, Helwig EB. Metastatic tumors of the skin. Cancer. 1972 May;29(5):1298-307.

17. Stein RH, Spencer JM. Painful cutaneous metastases from esophageal carcinoma. Cutis. 2002 Oct; 70(4):230-2.

18. Roh EK, Nord R, Jukic DM. Scalp metastasis from esophageal adenocarcinoma. Cutis. 2006 Feb; 77 (2):106-8.

19. Lookingbill DP, Spangler N, Helm KF. Cutaneous metastases in patients with metastatic carcinoma: a retrospective study of 4020 patients. J Am Acad Dermatol. 1993 Aug; 29(2 Pt 1):228-36.

\section{How to cite this article?}

Sridhar P, Nihanthy D S, Pallad S.R, Naveen T, Khaleel I, Govardhan. Cutaneous Metastasis of Esophageal Squamous Cell Carcinoma (ESCC).Int J Med Res Rev 2016;4(9):1632-1635.doi:10.17511/ijmrr. 2016.i09.20. 